\section{Let The Buyer Pay: International Trends In Funding For Higher Education}

\author{
Philip G. Altbach \\ Philip G. Altbach is J. Donald Monan SJ professor of higher education at \\ Boston College.
}

$\mathrm{T}$ he announcement by Britain's Labour government that free tuition for higher education will be ended signals a revolution in Britain and is part of a worldwide trend. Increasingly, the cost of higher education is shifting from the public purse to the individual. By American standards, the $\$ 1,600$ that university students in Britain will be asked to pay seems modest enough, but it represents a massive change in ideas about who should pay, and about the nature of a university education.

Worldwide, there are several patterns of funding university study. In Europe, the state typically still pays for the institutional costs of instruction; students pay little or no tuition, but are responsible for living costs; and most universities are public. In many Asian countries (such as Japan, Korea, Taiwan, and the Philippines), most students attend private universities and colleges and pay the full cost of their education. Tuition is also charged in the small and relatively elite public higher education sector. In the United States, a mix of public and private institutions exists; 80 percent of students attend public colleges and universities, where they pay tuition amounting to something like a quarter or more of the actual cost of instruction, with public funds and other resources covering the rest. The remaining 20 percent study in private institutions, where students pay the bulk of the cost of education.



Some poor countries provide totally free higher education. For example, most African countries today provide not only free tuition but virtually free room and board as well. The cost of supporting universities for the tiny proportion of the student-age population far exceeds the capability of governments facing severe economic difficulties.
Until recently, China also provided free higher education, but has moved to tuition-based arrangements. In countries in which most students attend private higher education institutions-some in Asia and a few in Latin America-students and their families pay for most of the cost of higher education. In countries dominated by the public sector, the state pays most of the bills.

The British decision signals the beginning of a major change throughout Europe. Discussions are underway in other European countries, and it seems only a matter of time until Europe's public universities charge tuition. This change is the result of a combination of demographic pressures, fiscal realities, and reinvigorated conservative ideas about public spending in Europe. These ideas are reflected worldwide, have been advocated by the World Bank, and are powerful in such diverse countries as the United States and China.

- The demand for access to higher education is high everywhere. University degrees mean higher salaries after graduation, and today's high-tech workplace requires the skills gained by university study. Until recently, many European countries educated only a small portion of the relevant age group in universities, and expansion has been rapid as universities struggle to meet demand. The United States educates close to half of its college-age population. In Europe, the proportions until recently were 20 percent or less. Now, the participation rate is growing, placing tremendous pressures on academic institutions.

- Sluggish economies and high rates of unemployment have restricted the money available for higher education, with the result that academic institutions have had to expand enrollments without adequate financial resources. In most European countries, universities have not been permitted to charge tuition, and there is no tradition of private philanthropy to higher education.

- There has been a shift in attitudes toward public spending of all kinds. People in most countries are reluctant to pay higher taxes, and this has resulted in less money being available from government resources for higher education. While the tradition of high tax rates and receiving 
more services from the state is entrenched on the European continent, "tax revolts" are occurring even there.

- A public consensus is growing that higher education is a "private good" primarily benefiting the individual rather than a social investment necessary for a modern economy. This perspective implies that the major cost of study at the postsecondary level should be borne by the individual rather than by society.

This powerful combination of forces is contributing to the current fiscal crisis of higher education. In the United States, we see the burden of funding higher education being shifted more and more to the individual — even the public universities are increasingly funded by nongovernmental sources, especially student tuition and fees, donations raised from alumni and others, and direct payment from businesses for services provided by the universities. Higher education is being asked to be more accountable for how its diminishing portion of public financial support is spent. Indeed, in many ways America's public colleges and universities are no longer public institutions, but rather "publicly assisted" nonprofit schools. Similar trends can be seen in Europe, but most countries are at the beginning of the transition to privatization of higher education.

\section{This powerful combination of forces is contributing to the current fiscal crisis of higher education.}

Britain is leading the European change. Students will be charged a modest (by U.S. standards) tuition, with loans available to low-income families. Further ideas include a "graduate tax" on university graduates, based on their incomes in the years following graduation, to provide further payment for higher education. This method of funding higher education is being tried in Australia and several other countries. Germany, whose rapidly growing higher education system is facing severe fiscal constraints, is also beginning to consider alternative methods of funding higher education. Most observers agree that standards have fallen in Germany's higher education system, and that an infusion of money is necessary to improve conditions. In all of these cases, the student will pay more for the privilege of studying.

Private higher education has expanded in many countries to provide access to large numbers without a rise in public funding. Privatization shifts the burden of paying for higher education to the student. Much of the expansion in Russia and in Central and Eastern Europe has been in the private sector. Latin America has also seen a dra- matic growth in private institutions. The new institutions tend to be vocationally oriented and specialize in fields where the cost of offering instruction is fairly low and the demand is high, such as management studies or computer technology. The quality of many of these universities is, at best, untested, and at worst highly questionable. New private colleges and universities are absorbing the demand for higher education, with few questions asked.

All of these changes will have dramatic implications for higher education worldwide. In Europe, where public funding was the norm and universities were of similar quality, academic systems are becoming more differentiated by quality and prestige. Since the 19th century, universities have been involved in basic research, and have been responsible for much of the scientific progress of the past century. Research is expensive, and it is not clear how it will be funded in the future. Without question, the "buyer" (students) will be paying more for higher education. How quality will be assured in these expanded and increasingly independent academic systems has yet to be determined. We are on the verge of profound international changes in patterns of funding, assessment, and access.

New Books Written or Edited by Philip G. Altbach

The Order of Learning: Essays on the Contemporary University, by Edward Shils (Edited and with an introduction by Philip G. Altbach). New Brunswick, N.J.: Transaction Publishers, 1997. 292 pp. \$34.95 (cloth) ISBN 1-56000-298-0. Available from: Transaction Publishers, Rutgers University, New Brunswick, NJ 08903, USA.

Student Politics in America: A Historical Analysis, by Philip G. Altbach. New Brunswick, N.J.: Transaction Publishers, 1997. 277 pp. \$24.95 (paperback) ISBN 1-560000-944-6. Available from: Transaction Publishers, Rutgers University, New Brunswick NJ 08903, USA.

The International Academic Profession: Portraits of 14 Countries, edited by Philip G. Altbach. Princeton, N.J.: Carnegie Foundation for the Advancement of Teaching, 1996. 762 pp. \$20 (paperback) Available from: Jossey-Bass Publishers, 350 Sansome St., San Francisco, CA 94104, USA

Higher Education Research at the Turn of the New Century: Structures, Issues and Trends, edited by Jan Sadlak and Philip G. Altbach. New York and Paris: Garland Publishing and UNESCO, 1997. 371 pp. \$75 (cloth) ISBN 0-8153-2505-3. Available from: Garland Publishing, Inc., 1000A Sherman Ave., Hamden, CT, USA. 